\title{
32. LITHOFACIES EVIDENCE FOR THE CRETACEOUS-PALEOGENE SEDIMENTARY HISTORY OF ERATOSTHENES SEAMOUNT, EASTERN MEDITERRANEAN, IN ITS REGIONAL TECTONIC CONTEXT (SITES 966 AND 967) ${ }^{1}$
}

\author{
Alastair H.F. Robertson²
}

\begin{abstract}
Drilling during Leg 160 penetrated an Early-Late Cretaceous and early Oligocene succession of carbonates in Hole 967E, beneath the lower northern slope of Eratosthenes Seamount. Middle Eocene pelagic carbonates were also recovered in Hole 966F, beneath the plateau area of the seamount. The base of the succession at Site 967 comprises shallow-water limestones, including coral and calcareous red algae, and occasional large foraminifers, that are interpreted as accumulations in a lagoonal setting within a carbonate platform. Neritic sedimentation ended in the upper Aptian (Lower Cretaceous) and was followed by an Upper Cretaceous pelagic carbonate succession that spans the interval from upper Cenomanian to Maastrichtian. Upper Cretaceous pelagic carbonates are locally organic rich and contain common replacement chert. In Hole 967E, Maastrichtian pelagic carbonates are unconformably overlain by lithologically similar chalks of early Oligocene age, with evidence of extensive reworking of older taxa. Minor tectonic instability is indicated by the presence of syndepositional neptunian dikes and fissures. In Hole 966F, middle Eocene pelagic chalks include reworked biota, chert, and organic-rich layers. The Eratosthenes Upper Cretaceous and Paleogene bathyal carbonates accumulated on a relatively level, submerged platform, isolated from terrigenous or gravity input. The transition from a shallow, carbonate platform to a bathyal setting (Turonian or earlier), took place before submergence of carbonate platforms in the Levant (in the Coniacian). Upper Cretaceous deposition on Eratosthenes is interpreted to have taken place seawards of a zone of high biogenic productivity that affected the Levant continental margin. Eratosthenes was also located well south of the zone of ophiolite genesis and tectonic displacement in the Upper Cretaceous. Overall, the Cretaceous and Paleogene carbonates of Eratosthenes are consistent with accumulation on an initially shallow, then submerged, carbonate platform isolated within a southern branch of the Neotethyan ocean, adjacent to the North African continental margin.
\end{abstract}

\section{INTRODUCTION}

An important discovery during Leg 160 is the presence, within the Eratosthenes Seamount, of pelagic carbonates of late Mesozoic and Paleogene age at Site 967 and Site 966 (Emeis, Robertson, Richter, et al., 1996). These sediments provide important insights into the deep-sea environments of the southern Neotethys ocean. Eratosthenes Seamount (Fig. 1) is assumed to be a crustal fragment that was detached from the North African continental margin in the early Mesozoic and was later subjected to collisional deformation in Pliocene-Pleistocene time (Kempler, 1994; Robertson et al., 1995). The deeper levels and structure of the seamount remain unknown, but are assumed to represent up to $5 \mathrm{~km}$ of sediment above a continental or igneous basement.

The purpose of this paper is to detail the lithofacies, diagenesis, depositional processes, and significance of the Eocene and Cretaceous carbonates for the sedimentary and tectonic development of Eratosthenes Seamount in its regional paleotectonic and paleoceanographic context within the southern Neotethyan ocean. The biostratigraphy utilized here is based on shipboard studies (Emeis, Robertson, Richter, et al., 1996) and more detailed postcruise studies (Premoli-Silva et al., Chap. 30, this volume).

\section{LITHOSTRATIGRAPHY Site 967}

Site 967 is located on the lower northern slope of the Eratosthenes Seamount and yielded the most important information. Lower Creta-

${ }^{1}$ Robertson, A.H.F., Emeis, K.-C., Richter, C., and Camerlenghi, A. (Eds.), 1998. Proc. ODP, Sci. Results, 160: College Station, TX (Ocean Drilling Program).

${ }^{2}$ Department of Geology and Geophysics, West Mains Road, Edinburgh University, Edinburgh, EH9 3JW, United Kingdom. Alastair.Robertson@glg.ed.ac.uk ceous shallow-water limestones are overlain by Upper Cretaceous pelagic limestones and then by middle Eocene pelagic limestone (Emeis, Robertson, Richter, et al, 1996; Fig. 2A, B). The recovery of the lowest part of the succession was restricted to a small number of fragments of mainly calcarenite, calcilutite, and chert. Above, the succession is mainly shallow-water bioclastic calcarenite and calcilutite. This is overlain by pelagic carbonates, with several thin intervals of dark, laminated organic-rich, fine-grained sediment. The interval between the shallow-water and pelagic carbonate units was recovered only as isolated limestone pieces, and may record a hiatus during Albian-lower Cenomanian (Premoli-Silva et al., Chap. 30, this volume). Alternatively, a transition may exist over 10-20 m, from shallow-water carbonate, through foraminifer-nannofossil chalk with mollusc debris and intercalated packstones, to uniform nannofossil chalk. There is no major lithologic change between dated intervals of Upper Cretaceous and Paleogene pelagic carbonates at Site 967. At Site 967, the Oligocene chalk is overlain by a short interval that comprises small angular clasts of micritic limestone in a weakly indurated nannofossil ooze matrix, with reworked planktonic foraminifers of middle Eocene, Oligocene, Miocene and late Miocene-early Pliocene age (Emeis, Robertson, Richter, et al., 1996; Premoli-Silva et al., Chap. 30, this volume). This shows that deep-water accumulation continued after the Miocene at Site 967.

\section{Site 966}

A much shorter interval, drilled at Site 966, is located on the northern plateau area of the Eratosthenes Seamount. Eocene sediments were encountered at about 300 mbsf (Section 160-966F-26R1), below a shallow-water carbonate sequence of Miocene age, as indicated by the presence of large benthic foraminifers (Emeis, Robertson, Richter, et al, 1996; I. Premoli-Silva, pers. comm., 1996; Fig. 2A). The contact with limestone of Miocene age is assumed to be an unconformity, as no transitional facies were observed.

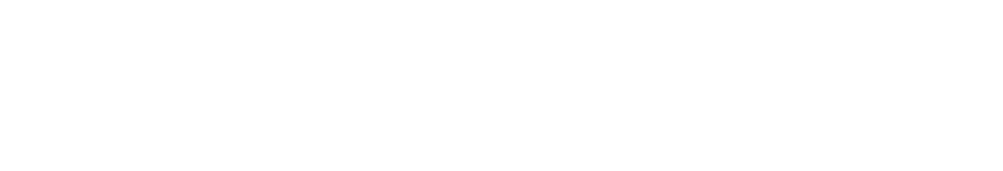




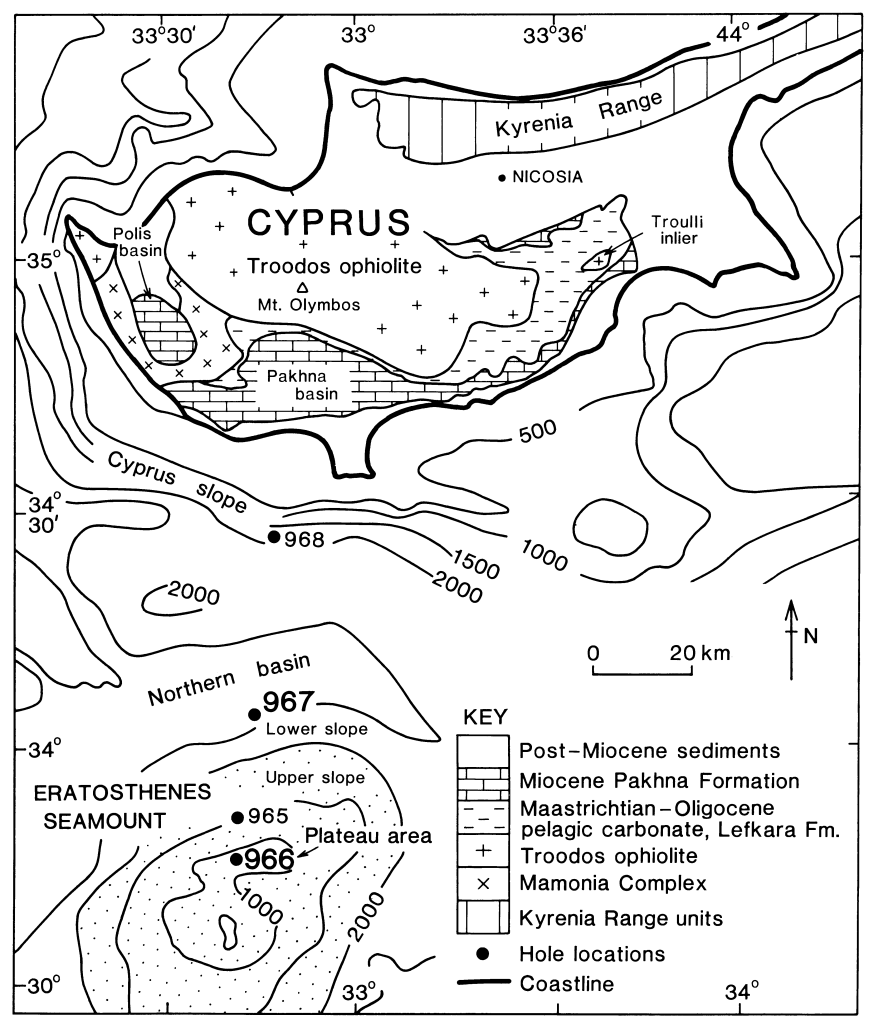

Figure 1. Geological map of Eratosthenes Seamount showing location of Sites 966 and 967, discussed in this paper, in relation to Cyprus. Note the distribution of Maastrichtian-Oligocene pelagic carbonates in southern Cyprus (Lefkara Formation).

\section{EARLY CRETACEOUS NERITIC CARBONATES}

\section{Lithofacies}

Shallow-water carbonates of late Aptian or older age were recovered from Hole 967E beneath the lower northerly slope of the Eratosthenes Seamount (Fig. 2B, units 3 and 4). These sediments provide an interesting insight into the early history of Neotethys in the easternmost Mediterranean. However, the recovery in each core was restricted to a small number of limestone and chert fragments that are assumed to have been derived from an originally bedded succession.

The fragments are mainly well-cemented calcilutite (grainstone and wackestone) and calcarenite (packstone) (Core 160-967E-34R). The coarser grained calcarenites contain abundant fragments of encrusting red algae, coral (Core 160-967E-37R), shell fragments (Fig. 3B-D), crinoid ossicles, other bioclasts, and micritic intraclasts (Cores 160-967E-37R, 160-967E-39R). In several cases, fragments of coral, calcareous algae, and other bioclasts are coated by calcareous algae (Core 160-967E-42R). Horizontal algal laminations are observed to bind sediment (Core 160-967E-41R). Finer grained packstones show traces of fine lamination, picked out by selective development of solution porosity (Core 160-967E-51R). The packstones (Core 160-967E-34R) in the upper part of the succession are clearly reworked. Evidence of reworking is also seen lower in the succession (Figs. 3F, 4E). FMS logs suggest the presence of subhorizontal bedding on a decimeter scale (Major et al., Chap. 38, this volume).

Clasts from higher levels in the succession include foraminifernannofossil chalk, similar to the overlying Upper Cretaceous pelagic carbonate succession (Core 160-967E-34R). Fine-grained carbonates show traces of lamination, weakly developed current rippling, burrowing (Core 160-967E-35R) and minor diagenetic moldic porosity.
A

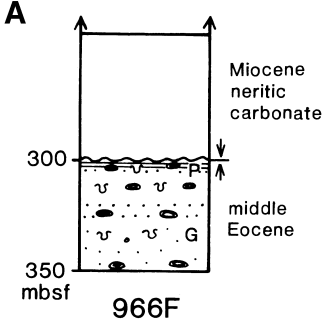

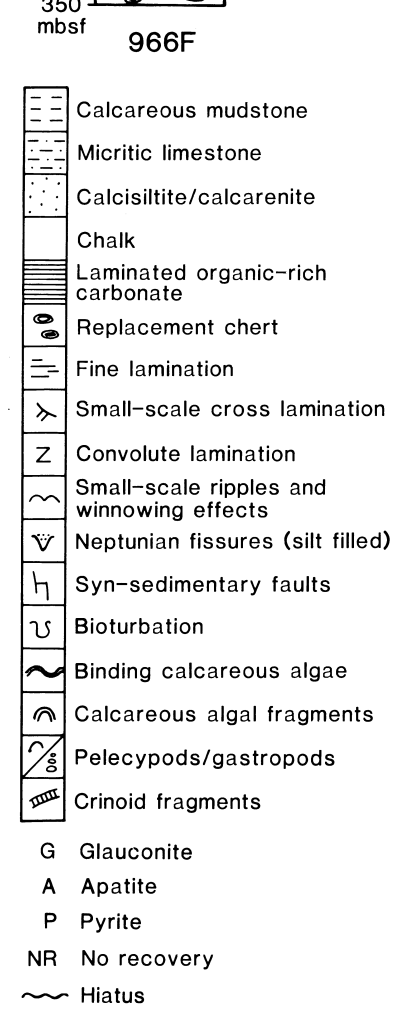

B

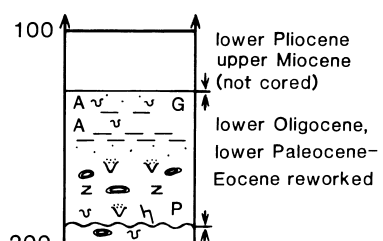

200

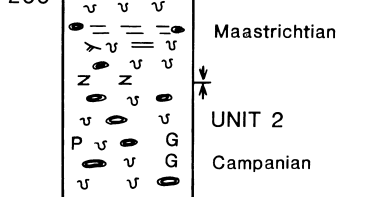

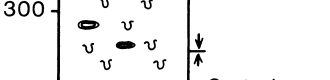

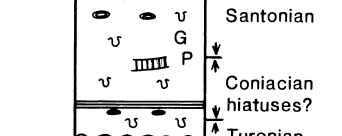

$400 \overbrace{r}^{\frac{r}{v} v^{2}}$

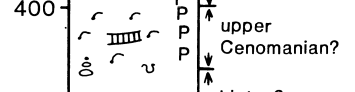

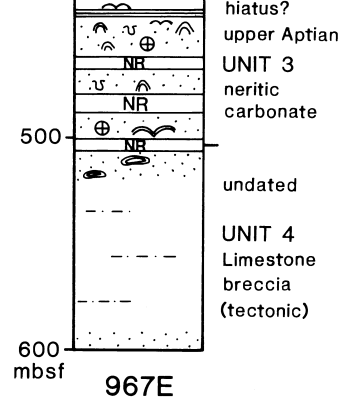

967E

Figure 2. Sedimentary log of the successions recovered at (A) Hole 966F and (B) Hole $967 \mathrm{E}$ on Eratosthenes Seamount. The recovery was often poor; thus, the $\log$ is generalized. Note the lower shallow-water carbonate succession at Hole $967 \mathrm{~F}$ and the depositional hiatus between the Upper Cretaceous and upper Eocene successions. The ages are as refined in Premoli-Silva et al. (Chap. 30, this volume).

Some dark, finely laminated, organic-rich? horizons are present (369.3-378.8 mbsf), together with occasional pyrite grains.

Minor chert, of replacement origin, is developed (Core 160-967E34R; Fig. 3A), as well as some pyrite. In some cases, the carbonate is locally too recrystallized to determine its original fabric (Cores 160967E-36R, 160-967E-41R; Fig. 3E). In other cases, moldic porosity is well developed, mainly following dissolution of bivalves and gastropods (Core 160-967E-34R; Fig. 3C). This secondary porosity is partly infilled with sparry calcite (Core 160-967E-36R). Radial calcite spar is also locally present (Fig. 5F).

\section{INTERPRETATION: A SHALLOW-WATER CARBONATE PLATFORM}

The carbonates formed in a shallow-water, low-energy type, or lagoonal, setting of Early Cretaceous age, where algae and coral flourished. This material is clearly reworked, but the presence of occasional layers of in situ binding algal laminae shows that deposition took place in shallow water. In the upper levels there is an incoming of pe- 

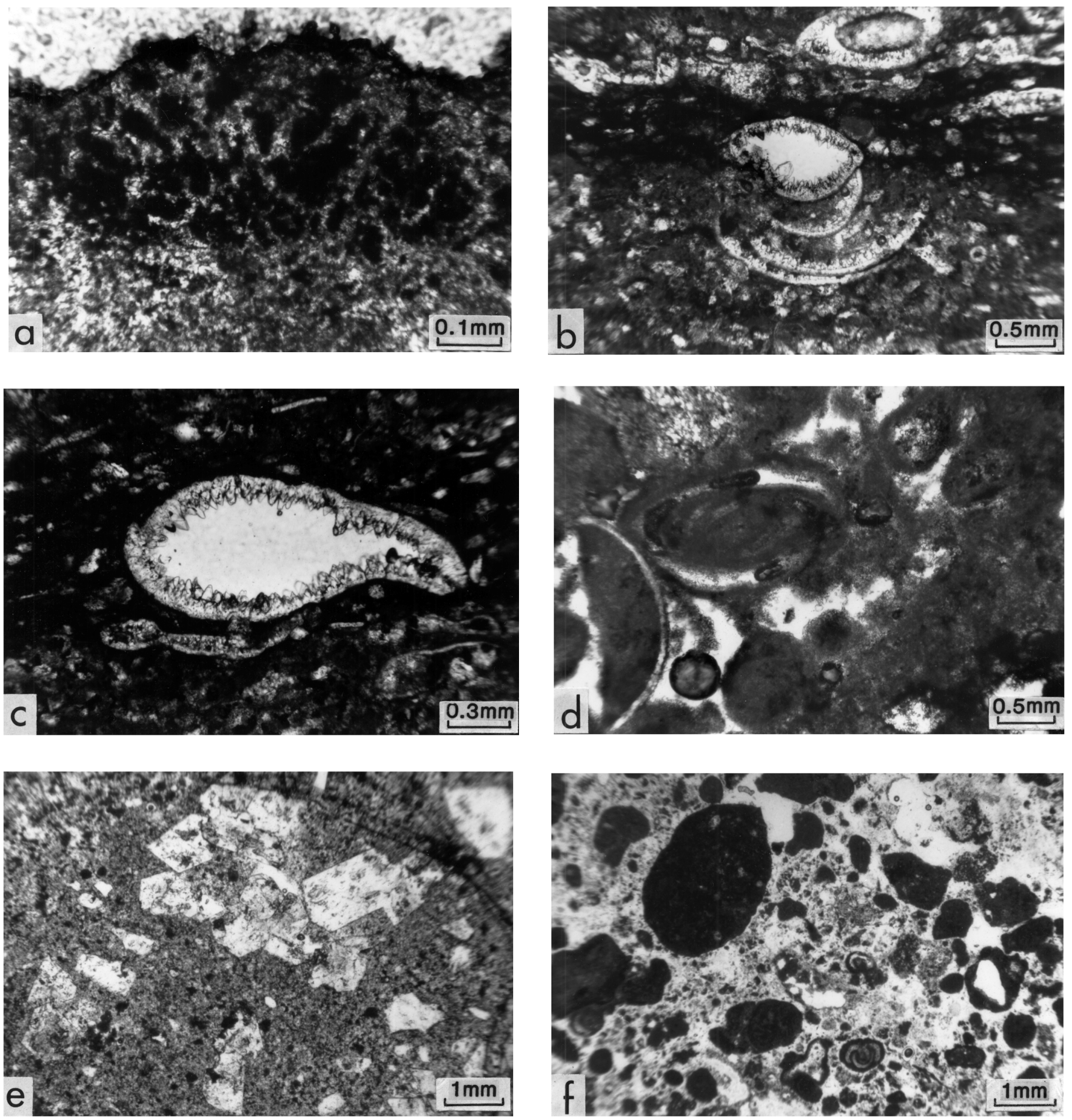

Figure 3. Photomicrographs of pre-Aptian part of succession in Hole 967E. A. Partly silicified carbonate. The pale, speckled material is microcrystalline quartz. The opaque grains are oxide formed during the process of silicification (Sample 160-967E-41R-1, 90-94 cm). B. Laminated carbonate with small shells, both intact and imbricated within shallow-water carbonate succession (Sample 160-967E-41R-5, 5-10 cm). C. Detail of one of the articulated small shells, as above. Note prismatic sparry calcite lining on interior of shell (Sample 160-967E-41R-1, 5-10 cm). D. Micritic peloids within the shallow-water carbonate succession; secondary porosity was created by partial dissolution (Sample 160-967E-41R-1, 90-94 cm). E. Secondary carbonate spar within biomicrite, probably dolomite (Sample 160-967E-45R-1, 14-16 cm). F. Reworked calcarenite containing micritic intraclasts (dark) and benthic foraminifers, set in a finer grained matrix (Sample 160-967E-41R-1, 90-94 cm). 

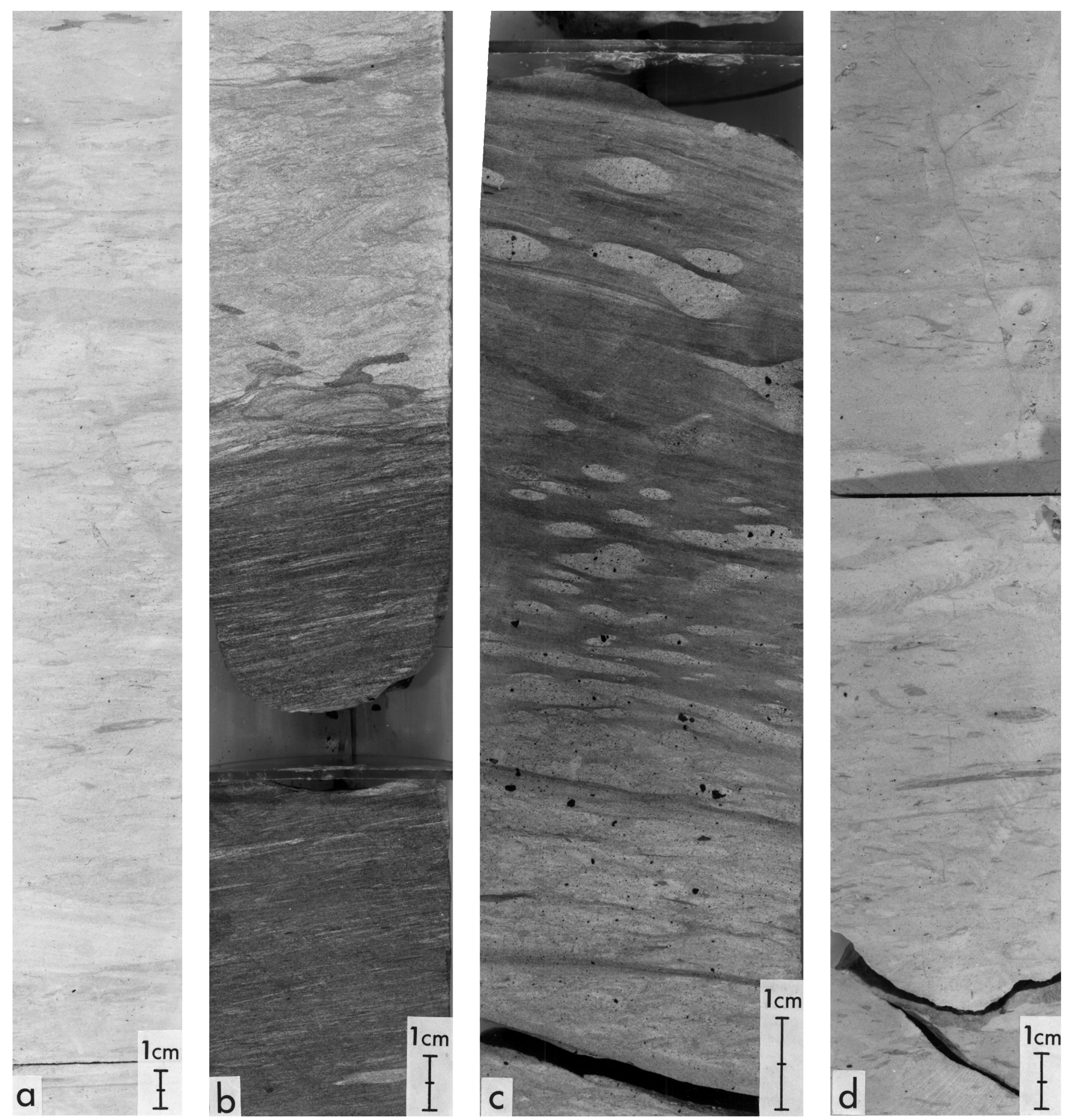

Figure 4. Photographs of Late Cretaceous and middle Eocene sediment cores. A. Typical middle Eocene pelagic carbonates showing bioturbation and remnants of planar lamination (interval 160-966-24R-4, 10-40 cm). B. Detail of finely laminated organic-rich layer in the middle Eocene succession (interval 160-966F30R-3, 20-40 cm). C. Bioturbated part of relatively organic-rich interval (interval 160-966F-27R-3, 23-33 cm). D. Typical highly bioturbated Late Cretaceous pelagic carbonates (interval 160-967E-17R-1, 50-70 cm).

lagic nannofossil ooze similar to that of the overlying Late Cretaceous succession, suggesting that submergence was taking place. The cessation of shallow-water deposition, before the advent of planktonic foraminiferal chalk, is assigned to a late Aptian age, based on the occurrence of Archaealveolina reicheli (Premoli-Silva et al., Chap. 30, this volume. The overlying samples from Cores 160-967E-35R and $-34 \mathrm{R}$ are interpreted as resedimented calcarenites interbedded within nannofossil chalk (Emeis, Robertson, Richter, et al., 1996). Overlying packstones with shallow-water-derived elements are envisioned as calciturbidites that were deposited during subsidence of the carbonate platform. During diagenesis, moldic porosity developed and there is some evidence of chert formation. Subsequently, particularly the lower part of the succession was strongly deformed tectonically and underwent recrystallization, veining, development of styl- 

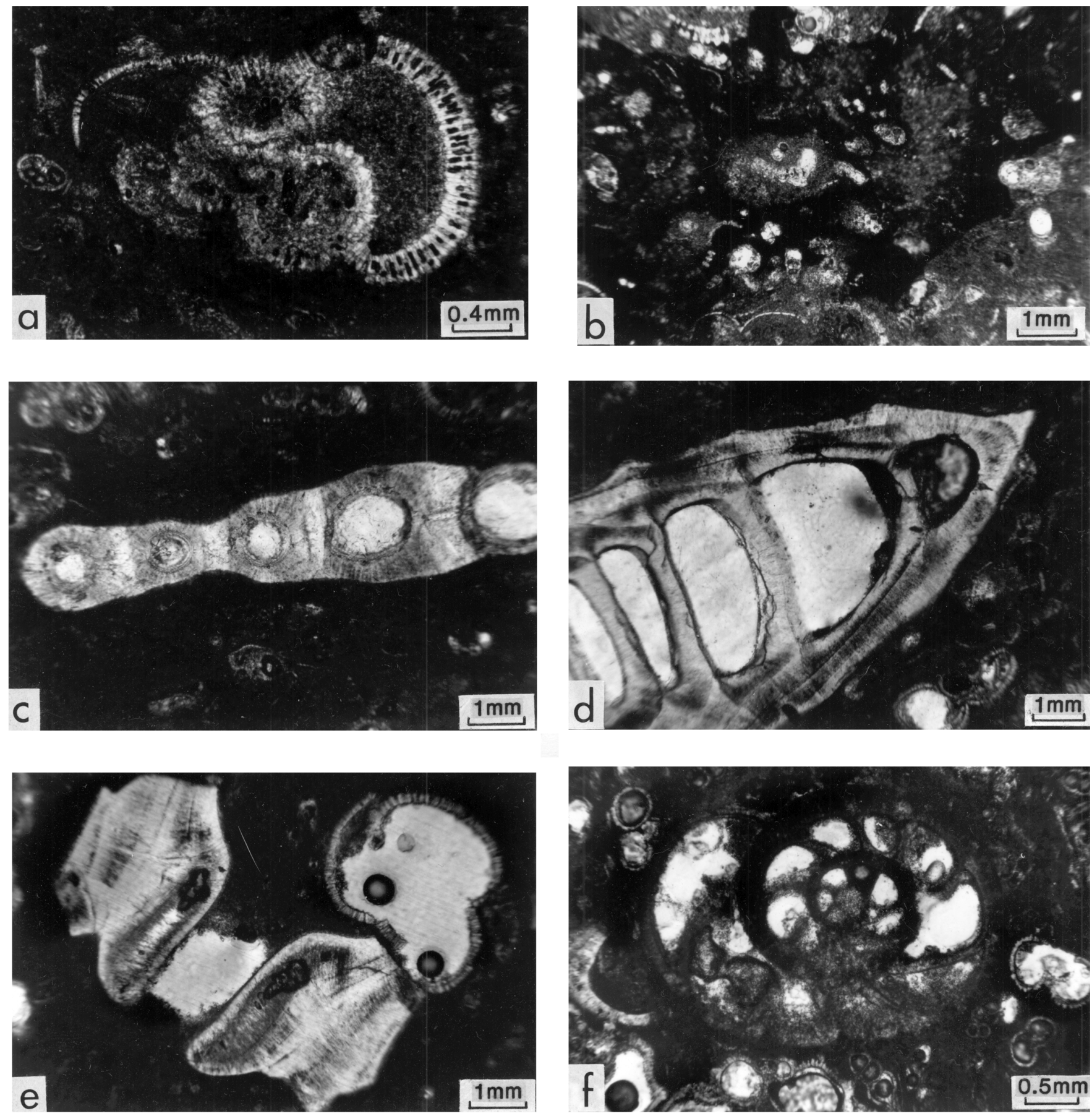

Figure 5. A. Detail of a poorly preserved planktonic foraminifer in Lower Oligocene pelagic micrite; test infilled with biomicrite (Sample 160-967E-4R-2, 94$98 \mathrm{~cm}$ ). B. Partly silicified Maastrichtian pelagic chalk. The pelagic carbonate is partly replaced by microcrystalline quartz (dark; Sample 160-967E-13R-1, 97$100 \mathrm{~cm}$ ). C. Part of benthic foraminifer within Lower Oligocene pelagic carbonate (Sample 160-967E-5R-1, 131-135 cm). D. Detail of part of benthic foraminifer within pelagic Lower Oligocene carbonate (Sample 160-967E-5R-3, 13-15 cm). E. Fragments of benthic foraminifers within Lower Oligocene pelagic carbonate (Sample 160-967E-5R-2, 13-15 cm). F. Benthic foraminifer within Maastrichtian pelagic carbonate (Sample 160-967E-12R-3, 128-133 cm). 
olites, and brecciation. This deformation is assumed to long postdate deposition and may be the result of Pliocene-Quaternary tectonics.

\section{LATE CRETACEOUS PELAGIC CARBONATES Lithofacies}

\section{Pelagic Chalk}

The dominant lithology throughout the sedimentary succession is grayish, or locally greenish, calcilutite with scattered planktonic foraminifers (Fig. 6D). The pelagic carbonate is typically well cemented. The color of the chalk varies from white to pale gray, commonly with centimeter-scale color banding. Planktonic foraminifers are locally abundant and give rise to a calcisiltite texture (Figs. 4B, 5A, B). Occasional benthic foraminifers are seen locally either intact or as fragments (e.g., Fig. 4F).

\section{Organic-Rich Layers}

Several organic-rich layers are noted as fragments within the Coniacian interval at Site 967 (Core 160-967E-28R; Fig. 6B). Finely laminated, black bituminous limestone was specifically noted between 370 and 380 mbsf (Core 160-967E-28R).

\section{Sedimentary Structures}

Bedding and lamination are mainly horizontal to subhorizontal or slightly inclined. Small-scale ripple laminations are very rarely observed (Core 160-967E-12R). Individual laminations are commonly picked out by concentrations of planktonic foraminiferal tests (Core 160-967E-11R; Fig. 5E) or inorganic calcite. Occasional examples of small-scale (millimeter to $2.5 \mathrm{~cm}$ ) convolute lamination are also noted (Core 160-967E-14R). By contrast, a number of fractures and faults are clearly of tectonic origin and are assumed to postdate lithification of the succession (Emeis, Robertson, Richter, et al., 1996).

\section{Bioturbation}

Alternations of more, or less, burrowed pelagic chalk are present throughout the entire succession (Core 160-967E-10R). The organicrich layers are generally amongst the most bioturbated. Planolites and Chondrites burrows are common (Cores 160-967E-9R, 160-96629R-1, 160-967E-29R), together with large Planolites (Core 160966E-29R-3), Zoophycos and relatively rare Teichichnus burrows (Core 160-967E-13R). Multiple cross-cutting burrow relations are locally observed. Some burrows are surrounded by purplish halos (possibly sulfide). However, where present, the organic-rich sediment is finely laminated and free of bioturbation (Fig. 3D).

\section{Macrofossils}

Fragmented echinoderm ossicles are observed locally in the Santonian and earlier parts of the succession (Cores 160-967E-26R, 160967E-31R, 160-967E-32R; Fig. 5B). In addition, small bivalves appear in the lower part of the succession at Site 967 (Core 160-967E32R). Large shell fragments and scattered mollusc debris (bivalves and rare gastropods) are also seen in the underlying Cenomanian interval (Core 160-967E-33R).

\section{Diagenesis}

\section{Chert}

An ubiquitous feature of the Upper Cretaceous pelagic chalk succession is the presence of scattered nodules of replacement chert, both as individual nodules and as chert layers. Some pelagic carbon- ate shows only incipient silicification (Fig. 4B). Representative occurrences are at Cores 160-967E-9R, 160-967E-11R, 160-967E-15R, 160-967E-16R, 160-967E-19R, 160-967E-22R, and 160-967E-24R. Log data suggest that chert is more abundant, but was rarely cored (Major et al., Chap. 38, this volume). Whole-rock X-ray diffraction of two chert samples revealed that one is entirely composed of quartz (Sample 160-967E-23R-1, 1-2 cm), while the other (Sample 160967E-19R-1, 0-6 cm) contains quartz, cristobalite (i.e., opal-CT) and calcite. Where chert is seen in situ, the fabric of adjacent carbonate is preserved within the chert (i.e., lamination, burrows, etc.). Locally, inclusions of unsilicified carbonate are preserved within individual nodules (Core 160-966F-26R-1).

\section{Glauconite}

Grains of green glauconite are scattered throughout Late Cretaceous and Oligocene pelagic chalk successions in Hole 967E (e.g., Section 160-966F-29R-3; Core 160-967E-25R). The glauconite is locally concentrated in burrows. Several of the glauconite-rich horizons are associated with pyrite (e.g., Core 160-967E-17R). Glauconite is most abundant between 340.5 and 350.1 mbsf.

\section{Pyrite}

Pyrite is present in the Late Cretaceous pelagic succession as minor to abundant disseminated framboids, crystalline pyrite cubes (Fig. 5C), and as thin, massive pyritic layers. In addition, occasional small (1-2 $\mathrm{mm}$ ) pyrite framboids are associated with organic-rich horizons (Core 160-967E-30R) and are rarely present elsewhere (Core 160-967E-31R). Occasional minor gray mottling effects are attributed to the presence of sulfide traces (e.g., Core 160-967E-12R).

\section{Apatite}

Small $(<3 \mathrm{~mm})$ scattered particles of brown apatite, of assumed biogenic origin, are frequent (Core 160-967E 12R).

\section{INTERPRETATION: UPPER CRETACEOUS BATHYAL DEPOSITION}

Pelagic carbonate accumulated at Site 967 during the Late Cretaceous (late Cenomanian?-upper Maastrichtian) in a quiet, deep-water setting. The carbonate accumulated as a pelagic rain at bathyal water depths (up to $1 \mathrm{~km}$ ), as indicated by the nature of the mainly pelagic biota. The sediment for the most part continuously accumulated under well-oxygenated conditions above the carbonate compensation depth (CCD) and was subject to extensive bioturbation. Sediment was periodically winnowed by bottom currents, producing concentrations of planktonic foraminifer tests, as individual horizontal laminae, and as gently inclined cross-lamination and rippled surfaces. However, the organic-rich intervals, mainly in the Coniacian, may reflect times of increased organic productivity or reduced circulation, allowing the oxygen-minimum zone to intersect the seafloor. There is no evidence of gravity deposition, and, specifically, pelagic calciturbidites are not present, which is consistent with accumulation on an isolated submerged platform. The calculated mean sedimentation rate is $8.5 \mathrm{~m} / \mathrm{m}$.y. (Premoli-Silva et al., Chap. 30, this volume). Major departures from this value are taken as evidence of hiatuses, notably in the Turonian-Coniacian time interval. The Cretaceous/Tertiary (K/ $\mathrm{T}$ ) boundary was not recovered, and, if sediments of this age accumulated, they were removed by later erosion. The presence of reworked Paleocene foraminifers indicates that pelagic accumulation continued into early Tertiary time. However, the bedding remains gently inclined throughout the Cretaceous-Paleogene interval, indicating that regional tectonic folding did not take place during this time. 

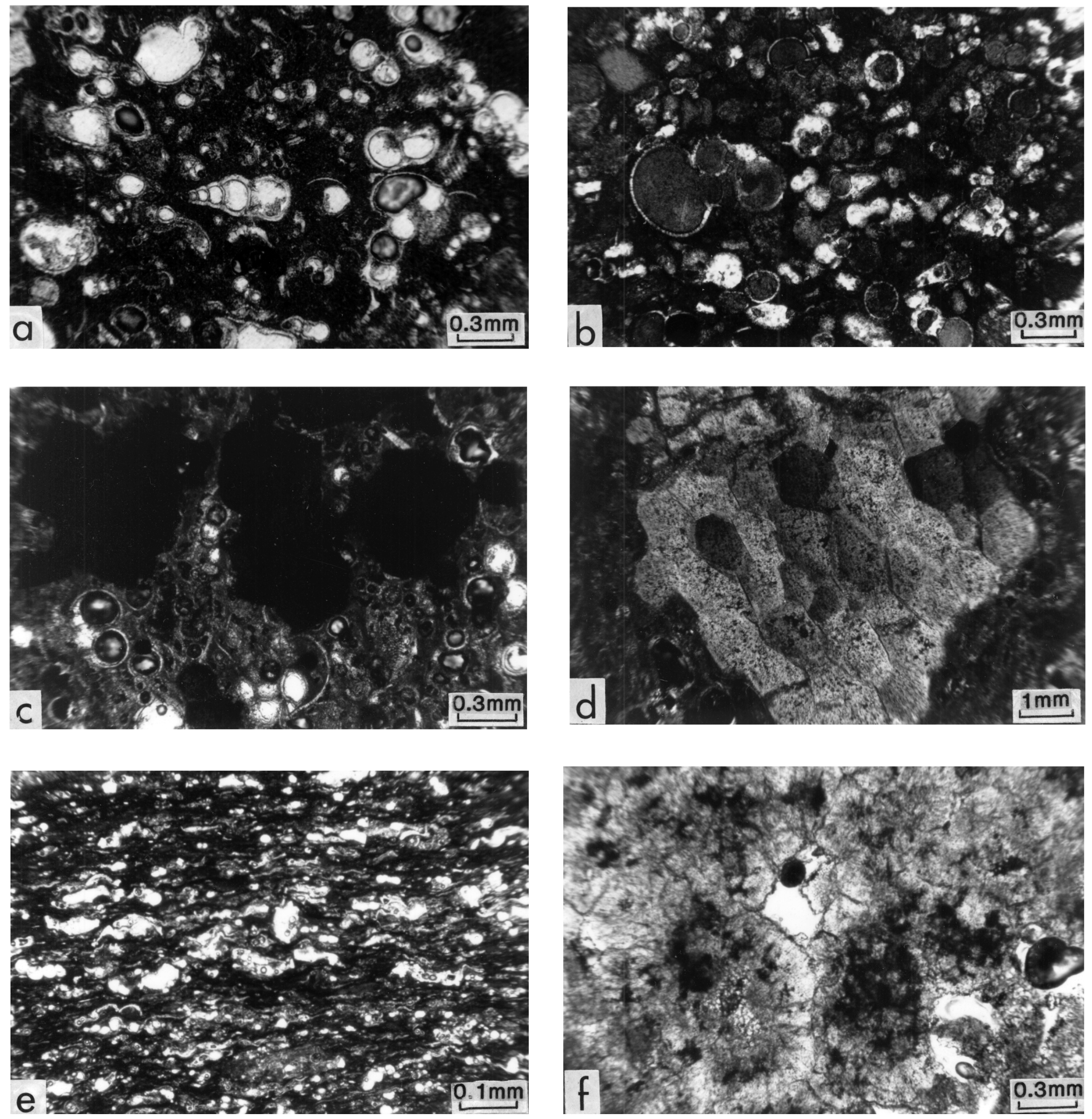

Figure 6. A. Planktonic foraminifers in Campanian pelagic carbonate (Sample 160-967E-17R-2, 50-55 cm). B. Planktonic foraminifers in Campanian pelagic carbonate (Sample 160-967E-17R-2, 50-55 cm). C. Diagenetic pyrite (black) within Campanian-aged organic-rich pelagic carbonate (Sample 160-967E-18R-2, 50-55 cm). D. Fragment of a crinoid ossicle within Late Cretaceous pelagic carbonate (Sample 160-967E-25R-3, 114-119 cm). E. Well-laminated, pre-Aptian aged, pelagic carbonate indicating seafloor current activity (Sample 160-967E-35R-1, 13-15 cm). F. Partly recrystallized pelletal carbonate within pre-Aptian succession showing preserved radial spar (Sample 160-967E-37R-1, 0-5 cm). 


\section{MIDDLE EOCENE PELAGIC CHALK}

Pelagic chalk of middle Eocene age was recovered in Hole 966F on the plateau area of the Eratosthenes Seamount (Fig. 1). These Eocene sediments were encountered at about $300 \mathrm{mbsf}$ (Section 160966F-26R-1), below shallow-water limestone that is assigned a Miocene age (Emeis, Robertson, Richter, et al., 1996). The top of the Middle Eocene interval is marked by high uranium contents, which might indicate that the overlying unconformity was marked by lower rates of sediment accumulation, possibly a hardground (Major et al., Chap. 38, this volume). Flecker et al. (Chap. 40, this volume) note that bedding in the middle Eocene and overlying Miocene sediments dips in different directions, which might suggest that the unconformity was associated with tilting.

\section{Lithofacies}

The chalk is lithologically very similar to the Upper Cretaceous chalk in Hole 967E described above. However, in the Eocene interval, laminae are commonly disrupted or obscured by bioturbation (Section 160-966F-17R-1; Fig. 6A-C). Planktonic foraminifers are again locally abundant (Section 160-966F-26R-3; see below). Thin partings of calcareous mudstone are rarely present (e.g., Sections 160-966F-26R-3, 160-966F-29R-1). The chalk is commonly color banded on a centimeter scale, mainly related to variations in organic carbon content. Chert nodules up to $4 \mathrm{~cm}$ in size occur sporadically.

The top few meters of the succession are dark gray and organic rich (up to 5.25\%; Emeis, Robertson, Richter, et al., 1996). This higher interval is composed of finely laminated, bituminous calcareous mudstone, with discontinuous, millimeter-thick laminae of carbonate silt (i.e., Sections 160-966F-26R-1 through 26R-3). Planktonic foraminifers are less abundant in the organic-rich interval compared to the underlying pelagic carbonate, and burrows are flattened (Fig. $3 \mathrm{C}$ ), possibly owing to lack of early cementation (Emeis, Robertson, Richter, et al., 1996). The organic-rich layers are enriched in uranium ( $~ 8$ ppm; Major et al., Chap. 38, this volume). Organic-rich muddy calcareous sediments were noted (e.g., Fig. 3B). The lower of these comprises a laminated organic-carbon-rich interval (Section 160966F-30R-1). This organic-rich sediment is intensely burrowed (mainly by Zoophycos) and includes occasional chert nodules and veins filled with secondary calcite (Section 160-966F-26R-3; Core $160-966 \mathrm{~F}-31 \mathrm{R})$. Traces of organic matter are also burrowed into the adjacent chalk (e.g., Section 160-966F-26R-2). Shipboard XRD analysis revealed small amounts of glauconite and fluorapatite (Emeis, Robertson, Richter, et al., 1996). In addition, a number of subhorizontal structures are attributed to tectonic shearing (or possibly slumping) that apparently took place before lithification of the sediments (Section 160-966F-29R-1; see Emeis, Robertson, Richter, et al, 1996).

\section{Interpretation: Middle Eocene Pelagic Deposition}

The occurrence of middle Eocene pelagic chalk in Hole $966 \mathrm{~F}$ shows that the settings of both these areas in the present northern plateau area (Site 966) and the lower slope (Site 967) of the Eratosthenes Seamount were very similar in Paleogene time. Quiet, deep-water pelagic sediment accumulation took place, as in the Upper Cretaceous interval of Hole 967E. The presence of several intervals of organicrich sediment suggests enhanced productivity or episodes of subsurface anoxia during middle Eocene time. The presence of reworked Cretaceous, early to middle Paleocene and early Eocene planktonic foraminifers (Premoli-Silva et al., Chap. 30, this volume) suggests that sediments of these ages were deposited locally, with the reworking probably resulting from bottom-current activity.

\section{OLIGOCENE PELAGIC CHALK}

Paleogene pelagic chalks were encountered in Hole 967F between 130 and 177 mbsf, with very similar lithological features to the underlying Late Cretaceous chalk. The first recorded Tertiary occurrence is Sample 160-967E-8R-1, 92-94 cm, which contains mixed assemblages encompassing the earliest Paleocene Zone $\mathrm{P}$ alpha to the late early Oligocene (Premoli-Silva et al., Chap. 30, this volume). Above this, the Oligocene foraminifer assemblage is mixed with foraminifers of early to middle Paleocene and early to middle Eocene age (Premoli-Silva et al., Chap. 30, this volume). There is thus an important hiatus between Maastrichtian and earliest Paleocene. Interpretation of log data suggests an unconformity is present at $177 \mathrm{mbsf}$ (Major et al., Chap. 38, this volume). The log evidence does not suggest that an interval of reduced sedimentation is present (e.g., hardground); thus, the hiatus is interpreted as a submarine erosion surface (Major et al., Chap. 38, this volume).

\section{Lithofacies}

The lithofacies and diagenetic features are very similar to those of the underlying Late Cretaceous succession (Fig. 4C-E). Planktonic foraminifers are locally concentrated producing a calcisiltite texture (Cores 160-967E-3R, 160-967E-4R; Fig. 4A). Lamination is locally slightly inclined, which provides additional evidence of current reworking (Core 160-967E-4R; Section 160-966F-29R-1). Individual laminations are marked by concentrations of planktonic foraminiferal tests (Core 160-967E-4R). In one case, a small slump $(20 \mathrm{~cm})$ was observed (Core 160-967E-6R), associated with a neptunian dike. Burrowing is common and includes Zoophycos traces (Core 160967E-3R). Color banding is often observed on a decimeter scale (Core 160-967E-8R). This commonly takes the form of fine millimeter- to centimeter-thick, pale green, sub-horizontal banding. Color mottling is also locally present (Core 160-967E-9R). The color effects are clearly of diagenetic origin, as shown by the fact that they pass through burrows without disruption (Core 160-967E-8R).

Chert of replacement origin was rarely cored, but is correlated with numerous resistive intervals on FMS logs (Major et al., Chap. 38 , this volume). Individual chert nodules are composed of dark gray microquartz, with locally preserved white rinds up to $2 \mathrm{~mm}$ thick (e.g., Core 160-967E-6R). Where chert is seen in situ, the fabric of the adjacent carbonate is preserved within the chert (i.e., lamination, burrows, etc.). Minor to abundant disseminated pyrite is also present (Core 160-967E-8R), together with scattered apatite.

Evidence of syndepositional, or early post-depositional, deformation was occasionally noted. A small number of minute faults with offsets of $<2 \mathrm{~mm}$, appear to have formed before cementation and thus cannot have formed as a result of drilling disturbance (e.g., Core 160967E-8R). A small number of fissures on a centimeter scale are infilled with carbonate silt (Core 160-967E-8R). In one case (Core 160967E-9R), a small ( $<3 \mathrm{~cm}$ ) depression in laminated chalk apparently formed by early diagenetic syndepositional "collapse," and was later infilled with massive chalk. This syndepositional feature is interpreted as a neptunian dike, infilled with Chondrites-burrowed chalk (Core 160-967E-6R).

\section{Interpretation: Oligocene Bathyal Pelagic Carbonate Accumulation}

The continuation of deep-water, pelagic carbonate sedimentation from the Cretaceous into the Tertiary in Hole 967E (Premoli-Silva et al., Chap. 30, this volume) indicates that Eratosthenes Seamount remained in a relatively stable tectonic setting. Minor tectonic instability is shown by the occurrence of contemporaneous neptunian fis- 
Age \& Lithology

A

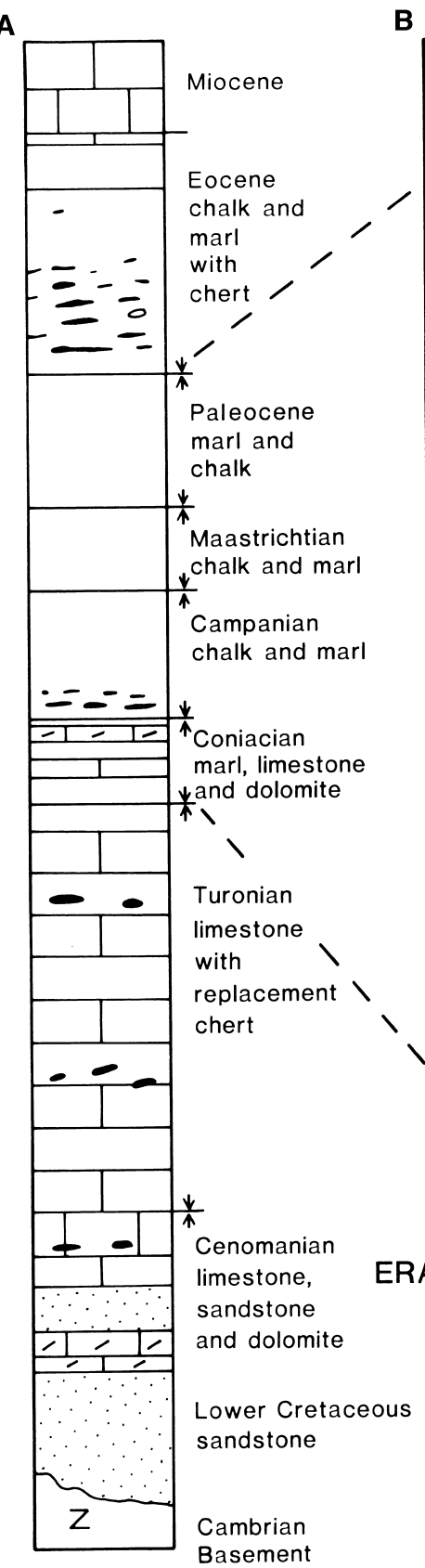

LEVANT
B

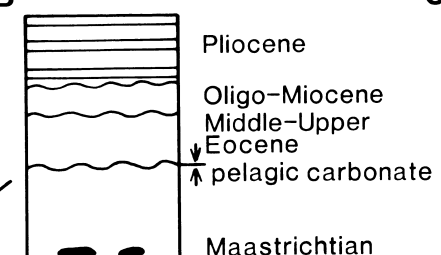

- Maastrichtian

-

- Pelagic

with

replacement

chert

nodules

Upper

Cretaceous

(see Fig.2b.)

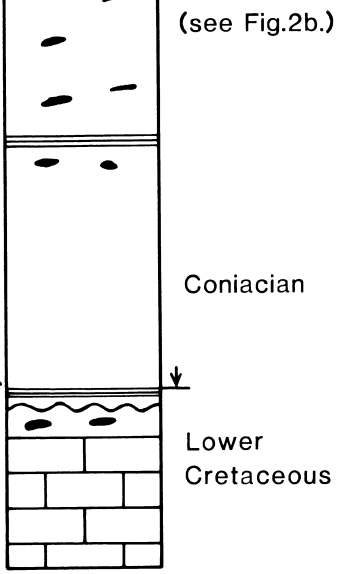

ERATOSTHENES

SITE 967
C

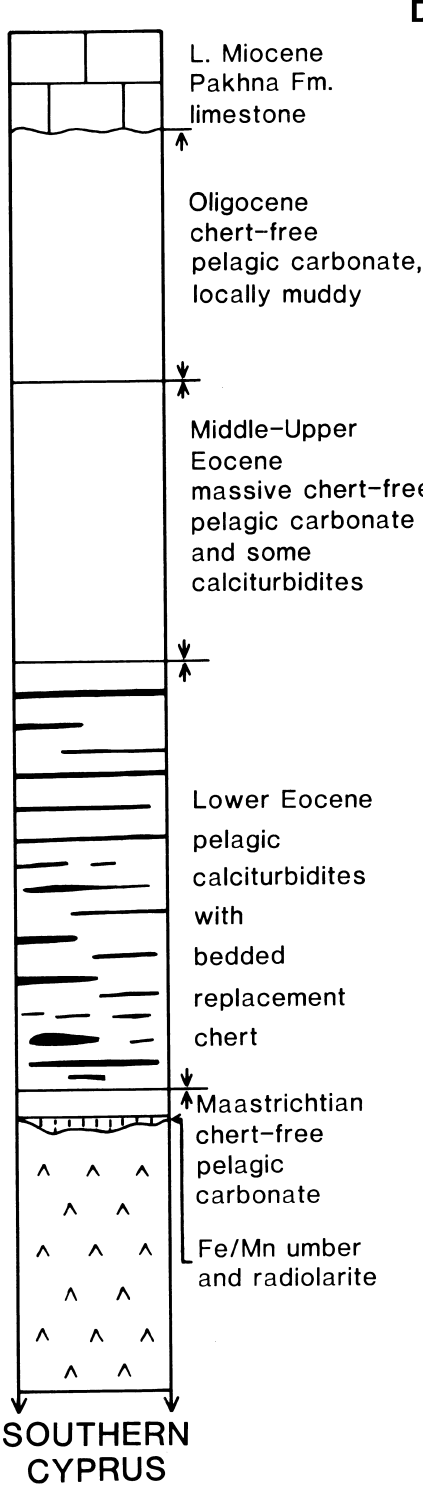

D

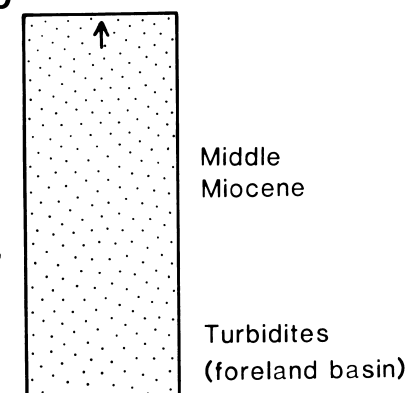

(foreland basin)

Lower Miocene

Transgression

Ophiolitic clastics

Upper Paleocene-

Lower Eocene

Senonian

Turonian Organic-rich layers

$\left[\begin{array}{l}0 \\ 50\end{array}\right.$ metres

Limestone

$\underbrace{1}_{-1,1}$ Lime

\begin{tabular}{lll}
\hline \multicolumn{1}{|r}{-1} & Dolomite \\
\hdashline$\because \because$ & Sandstone
\end{tabular}

i i i i Metalliferous sediment

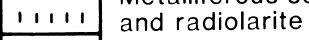

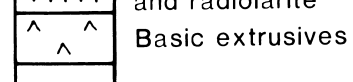

Chert
Cenomanian

,

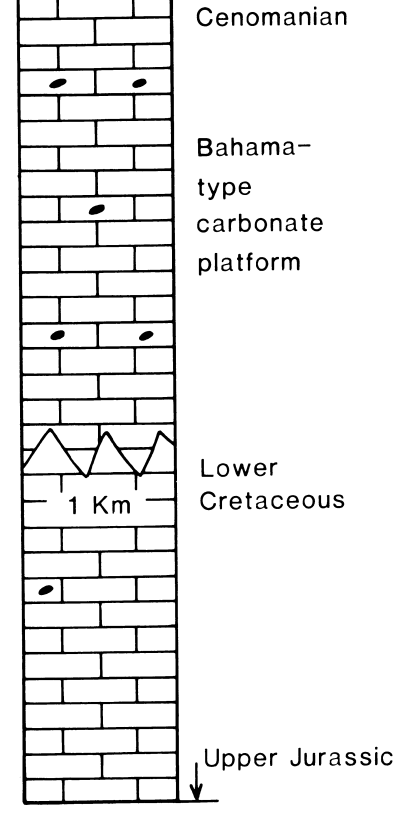

SOUTHERN

TURKEY

Bey Dağları

Figure 7. Summary logs of stratigraphic successions in the (A) Levant, (B) the Eratosthenes Seamount, (C) southern Cyprus, and (D) southern Turkey. The Levant and Eratosthenes successions are similar, but those in Cyprus and southern Turkey differ considerably, which is consistent with the existence of a plate boundary located between Cyprus and Eratosthenes Seamount. 
sures that may relate to syndepositional faulting. Relatively high productivity is suggested by the occurrence of scattered chert nodules of replacement origin. The apparent absence of the late Paleocene, late early Eocene, late Eocene, and probably earliest Oligocene intervals in Hole 967E points to the existence of significant hiatuses in deposition, presumably in response to bottom-current activity. However, this was possibly facilitated by faulting.

\section{REGIONAL COMPARISONS}

The Cretaceous and Paleogene carbonate successions of the Eratosthenes Seamount can be compared with well-documented successions onshore in the Levant, southern Cyprus, southern Turkey (Fig. 7), and elsewhere in the Mediterranean area, including Italy.

\section{Levant}

The succession can be summarized as follows (Bartov et al., 1972; Garfunkel, 1988; Y. Arkin, F. Hirsch, R. Roded, and A. Flexer, unpubl. data; Mart et al., 1997; Fig. 7A).

Cambrian basement units in the southern Negev and Sinai are unconformably overlain by terrestrial sandstones, intercalated with alkaline volcanics (with localized marine intercalations), of Early Cretaceous age. These units are in turn overlain by transgressive Cenomanian dolomites, shallow-water sandstones, and shelf carbonate with nodules of replacement chert. During the Turonian, dolomite disappeared and terrigenous intercalations are mainly represented by clay. Shallow-water carbonates with replacement chert were then deposited in the late Turonian. The early Coniacian saw the end of shallowwater platform carbonate deposition. In the northern Negev there is a unconformity that may record exposure and erosion during the Coniacian-Santonian.

A regional marine transgression took place during the Late Cretaceous, reaching an estimated maximum water depth of $1000 \mathrm{~m}$ in Maastrichtian to Eocene time, as inferred from the planktonic foraminifers and calcareous macrofossils present. Throughout this time, the background deposition was pelagic chalk and marl, with variable additions of phosphorite and silica. Typical depositional rates of this 200-500 m-thick pelagic carbonate succession from the late Coniacian to the end of the Cretaceous ranged from 9-23 mm/k.y. (Gvirtzman et al., 1989), higher than the average rate on Eratosthenes (8.5 $\mathrm{m} / \mathrm{m}$.y.). The Santonian portion of this succession is dominated by massive, white chalk, with minor phosphorite and brown chert. During the Santonian, a transition to deeper water pelagic carbonate deposition took place. The early Campanian is marked by an important interval of chert (Kolodny, 1980; Steinitz, 1977, 1981). The stratigraphically lower part of this succession is represented by partially silicified chalk and porcellanite with chert concretions, followed by $20-30 \mathrm{~m}$ of brecciated gray to reddish chert. The chert is overlain by a 40-m-thick unit of alternating phosphorite, phosphatic chalk, porcellanite, limestone, and thin cherts, then overlain by pelagic chalk and marls (Nathan et al., 1979). Overlying Maastrichtian chalk is variable in thickness (up to $76 \mathrm{~m}$ ) and includes phosphates and hydrocarbon-rich shales (Shahar, 1968). The K/T boundary is marked by a minor hiatus. Muddy sediments accumulated in the Paleocene, together with chalk and chert, and both ferruginous and barite concretions.

The Santonian to late Maastrichtian time interval ( 19 Ma) was marked by upwelling, with high paleo-productivity and reduced-oxygen levels on the seafloor, along much of the southern margin of Tethys (i.e., the northern margin of Gondwana), including the Levant (Almogi-Labin et al., 1991, 1993). This period corresponded to a regional transgression and an eustatic sea level high (Haq et al., 1987). Conditions were mostly anoxic in relatively shallow, restricted, inner-shelf settings, passing to dysaerobic to oxygenated in relatively deep, more open, outer-shelf settings, over a distance of $\sim 100 \mathrm{~km}$. Much of the chert is assumed to have been derived from diatoms that are no longer preserved. Also, high productivity of certain planktonic foraminifers is known to be controlled by nutrient availability in a number of modern marginal settings (e.g., Gulf of California; Almogi-Labin et al., 1993). The marginal upwelling system was established in the late Coniacian-early Santonian to early Campanian, reached a stable maximum in the middle to late Campanian, and then declined in the early Maastrichtian. Deposition within the inner basins was probably entirely within the oxygen-minimum zone, while the outer basin was on the margins of the oxygen-minimum zone. During the Maastrichtian, the center of upwelling appears to have migrated $\sim 200 \mathrm{~km}$ southeast and was associated with a transgressive cycle. The Eratosthenes Seamount lacks this bedded chert interval and is assumed to have been located seaward of the zone of high productivity.

During the Senonian-Paleocene, regional tectonic movements gave rise to the S-shaped Syrian arc, characterized by en echelon anticlines and synclines that extend from the Palmyrides in the north to Northern Sinai in the south and exerted an important control on deposition. Syndepositional movements along this structure gave rise to folding, faulting, and soft-sediment deformation (slumping), and was marked by reduced deposition of sediments on the crests of fold structures. The main cause of deformation is inferred to be incipient collision and amalgamation of exotic terranes including ophiolites along the northern margin of the Arabian plate (Robertson, Chap. 54, this volume). A minor echo of these events may have given rise to faulting and sediment instability on the Eratosthenes Seamount during the same time interval.

Pelagic chalk accumulated on a more subdued seafloor topography in the early Eocene and is intercalated with chert, or porcellanite, at a time of inferred eustatic sea-level high. Overlying nummulitic limestones, especially in the eastern and southern margins of the basin, show marked local facies variation and are intercalated with pelagic carbonates. At the end of the early Eocene, the Syrian arc was reactivated, leading to regional tectonic instability with widespread slumping of pelagic carbonates that had accumulated in a gently sloping ramp setting. Moreover, eustatic sea level was lowered, which may have contributed to erosion and soft-sediment instability. Extensive slumping was coupled with development of debris flows and mud flows composed of pelagic lithofacies (Buchbinder et al., 1988). Silica production decreased during the middle Eocene. The overall cause of tectonic instability is inferred to be a northward convergence of the Arabian plate and the initial stages of continental collision in the north. A regional regression took place in the late Eocene, resulting in exposure, erosion, and reduced sedimentation, especially along the coastal plain. The Miocene was characterized by emergence and accumulation of conglomerates and lacustrine deposits, related to the rifting of the Dead Sea system to the east. Tectonic events in the Levant may again be echoed in the Eratosthenes Seamount. Specifically, it is possible that the erosion of the pre-middle Eocene, Paleogene succession took place, related to movements within the Syrian arc, which took place immediately after the end of early Eocene time. Such movements could also have triggered reworking of the Eocene or Paleocene succession at Site 967. In general, tectonics, rather than eustatic sea level change is seen as the main control of sediment hiatuses and unconformities, as the Eratosthenes Seamount formed as an isolated feature away from the influence of coastal transgressions and regressions.

\section{Southern Cyprus}

Late Cretaceous pelagic carbonates are well exposed in Cyprus, where they depositionally overlie the Troodos ophiolite (Robertson and Hudson, 1974; Fig. 7C). Pelagic carbonates of Upper Cretaceous age are also present in the Kyrenia Range of Northern Cyprus 
(Melounda Formation), where they are intercalated with basic and acidic volcanic rocks (Ducloz, 1972; Baroz, 1979; Robertson and Woodcock, 1986).

The Troodos ophiolitic extrusives are overlain by metalliferous mudstones (umbers) and radiolarites of Campanian age. These siliceous sediments reflect a regional high productivity event within the Neotethys, rather than accumulation below the CCD (see Robertson et al., 1991 for review of literature). The high productivity event also gave rise to the siliceous and phosphatic sediments on the Levant margin, mentioned above.

Pelagic carbonate successions overlying the Troodos ophiolite, known as the Lefkara Formation (Mantis, 1970), are divided into three units: the first is a Maastrichtian chalk (Lower Lefkara Formation) ponded into broad hollows on an irregular volcanic surface. Very little or no chert is present in this unit. The pelagic carbonate

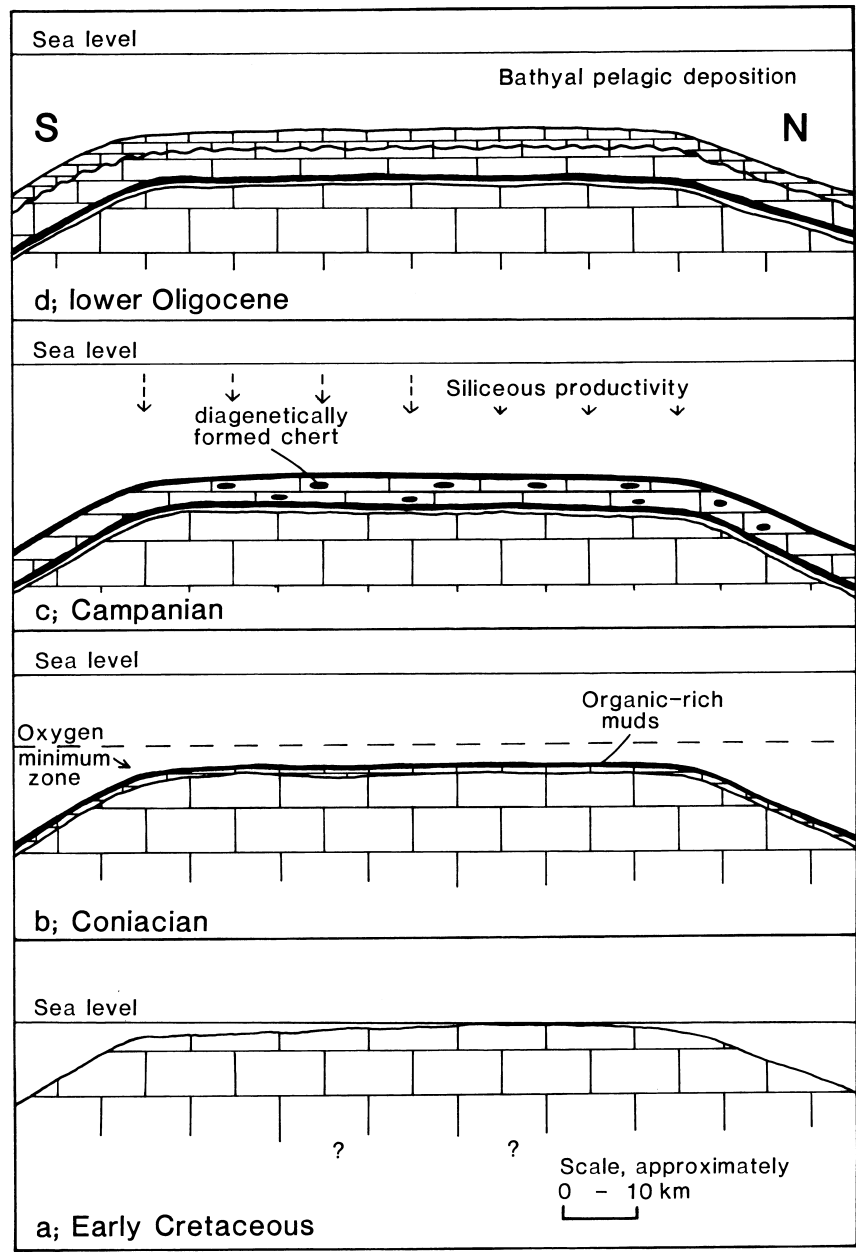

Figure 8. Depositional model for the Late Cretaceous and middle Eocene successions on the Eratosthenes Seamount. A. Early Cretaceous. The seamount forms part of a relatively level carbonate platform isolated within the Neotethys ocean. The basement is unknown but is assumed to be additional platform carbonate above a substratum of stretched continental crust, associated with dense igneous bodies. Facies in Eratosthenes are mainly lagoonal. B. Coniacian. Eratosthenes has subsided and is overlain by pelagic carbonate; the seamount is periodically below the oxygen-minimum zone, allowing laminated organic-rich carbonates to accumulate. C. Campanian. Deposition of relatively siliceous sediment related to regionally high productivity, followed by genesis of common replacement chert (recovered only as fragments). D. A hiatus is followed by further pelagic carbonate deposition of Lower Oligocene age. succession continues without an obvious break into the lower Tertiary, as the Middle Lefkara Formation. This is divided into a lower unit, of late Paleocene-early Eocene age, which contains numerous pelagic calciturbidites and is also very rich in replacement chert. Above, is a massive, chert-free unit, in turn overlain by more marly, generally chert-free chalk, of mainly late Eocene-Oligocene age (Upper Lefkara Formation). The redeposited layers contain minor terrigenous sediment mainly derived from the Troodos ophiolite, but rare biotiteand quartz-rich acidic volcaniclastic sediment is also rarely observed. Recent biostratigraphical work by Krasheninnikov and Kaleda (1994) suggest that the chert is mainly within the lower Eocene part of the succession. Marked shallowing and onset of more muddy hemipelagic deposition ensued, giving rise to the Miocene Pakhna Formation (Eaton and Robertson, 1993). The early Tertiary pelagic deposition varies markedly in thickness and facies around different parts of the Troodos ophiolite. In the south, the succession exceeds $1000 \mathrm{~m}$ in thickness, mostly consisting of pelagic calciturbidites (Robertson, 1976). By contrast, the pelagic chalk succession is much thinner and lacks evidence of deposition around the northern and western margins of Troodos. In general, the contrasting pelagic chalk facies record marked tectonic instability, in part related to the later stages of paleo-rotation of the Troodos microplate (Clube and Robertson, 1986). Recently, the biostratigraphy of one section of the Upper Cretaceous and Paleogene-Neogene sedimentary succession (i.e., the Perapedhi Formation in southern Cyprus) was restudied in detail (Krasheninnikov and Kaleda, 1994; Khokhlova et al; 1994) leading to refinement in the dating.

Replacement chert in Cyprus formed by dissolution of siliceous microfossils (i.e., radiolarians and diatoms). The chert originated as opal-A, and is now largely preserved as opal-CT, with some quartz development (Robertson, 1977). The chert exhibits several different forms in different areas. In southern Cyprus, the chert is mainly elongate nodules and lenticles that formed preferentially in the relatively porous intervals of calciturbidites (Robertson, 1977). Along the northern margins of the Troodos ophiolite the chert is in the form of elongate nodules within pink, condensed chalk. In western Cyprus, the chert forms elongate nodules or bands within white, generally structureless chalk.

The late Cretaceous-Paleogene succession in southern Cyprus thus differs drastically from that of the Eratosthenes, in the following main ways: (1) The succession in southern Cyprus is much more continuous; (2) Campanian radiolarian cherts are absent on Eratosthenes; (3) The main interval of early Eocene chert formation in Cyprus is represented only by reworked calcareous microfossils at Eratosthenes; (4) The Cyprus Paleogene pelagic carbonates accumulated were largely redeposited under probable tectonic influences, whereas the Eratosthenes pelagic carbonates accumulated in a more stable setting without development of calciturbidites.

\section{Southern Turkey}

In many areas, Late Triassic-middle Cretaceous intervals of the succession are dominated by the development of large carbonate platforms of Bahama type, for example, in the Antalya region (Poisson, 1979; Fig. 7D). However, during the early Late Cretaceous these platforms were regionally submerged and overlain by pelagic carbonates. Widespread shallow-water carbonate deposition ended in the Cenomanian and was followed by the initiation of pelagic carbonate deposition in the Turonian. The event was apparently related to regional tectonic movements and transgression. Pelagic deposition then continued during the early and late Senonian until early Paleocene time when accumulation was terminated by final emplacement of allochthonous units over the margin (the Antalya Complex; Poisson, 1979; Poisson et al., 1984). The causes of the submergence are unknown, but could include a regional, eustatic sea-level rise, or tectonic subsidence related to the breakup of carbonate platforms. In the 
Antalya region submergence was accompanied by deposition of carbonate breccias that are interpreted to have been shed from active fault scarps (Robertson, 1993). At the end of the Cretaceous, tectonic deformation associated with the emplacement of ophiolites affected many parts of the northern periphery of the Eastern Mediterranean, including southern Turkey and Syria (Robertson and Woodcock, 1980; Şengör and Yilmaz, 1981). Subsequent pelagic sedimentation of early Tertiary age is very restricted in these areas, and where present, is often associated with coarse, syntectonic clastic sediment input (e.g., in the Antalya Complex; Robertson, 1993).

\section{DISCUSSION}

During the Late Cretaceous (Cenomanian-Maastrichtian), ophiolites, including the Troodos, were created at spreading centers within the Neotethyan ocean, and then deformed or tectonically emplaced
(Troodos ophiolite; Moores and Vine, 1971). Current interpretations suggest the Troodos ophiolite formed by spreading above a subduction zone that was probably northward dipping, rather than at a conventional mid-ocean ridge (see Robertson et al., 1991, for literature review). No trace of these upheavals is preserved in the Eratosthenes Seamount succession. This Site 967 region instead continued to undergo quiet, bathyal deposition during the Late Cretaceous and well into Paleocene time. The probable reason for this is that the seamount was still located some distance south of areas of active deformation, forming part of the North African plate, whereas the tectonic deformation and ophiolite emplacement was associated with microplate displacement within the Neotethys further north.

The Upper Cretaceous and middle Eocene Eratosthenes pelagic successions are remarkably similar, yet the Paleocene, which is well represented in other areas (Cyprus, Levant), is apparently poorly represented, perhaps because of later reworking.

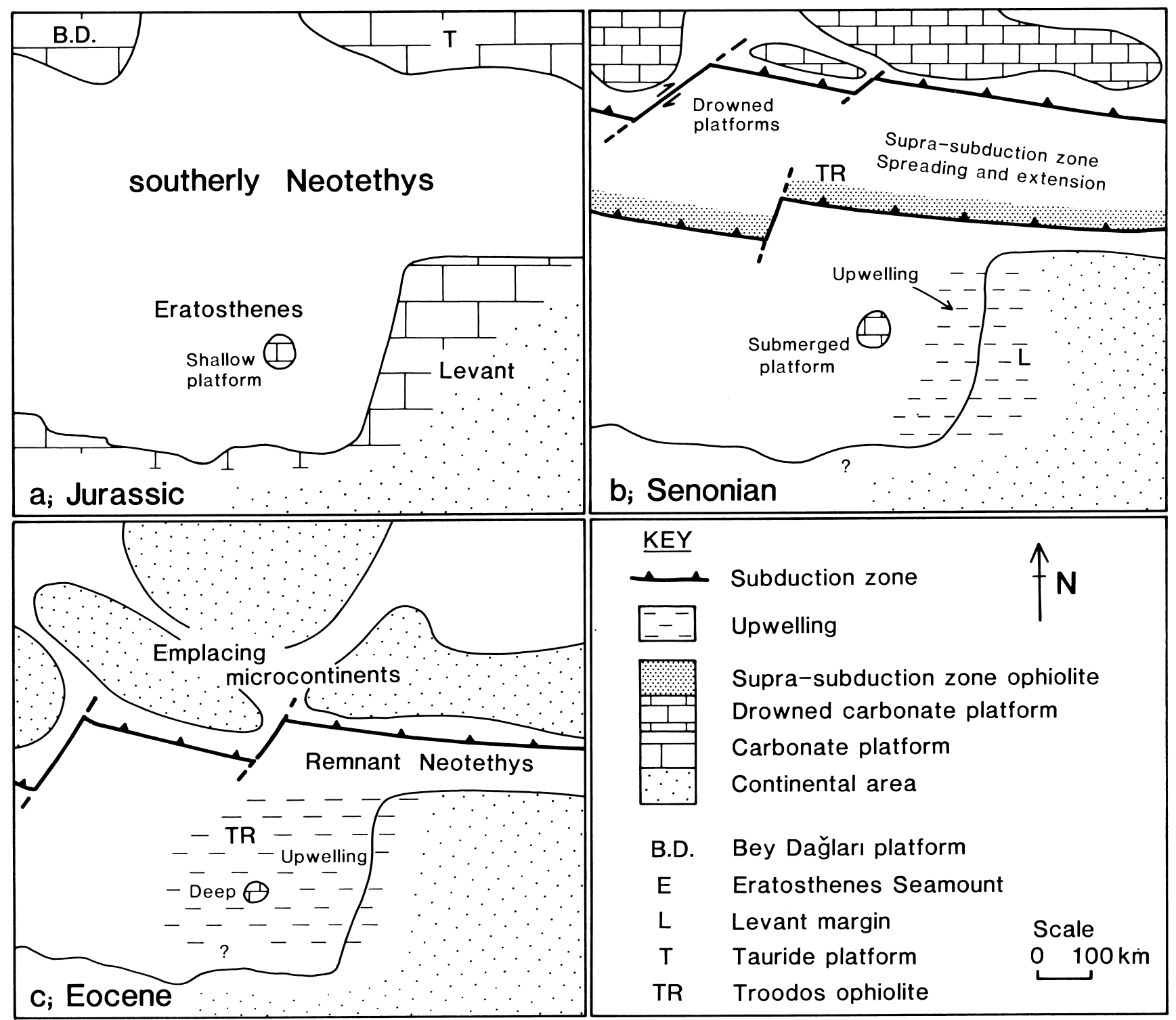

Figure 9. Paleogeographical sketch maps of the easternmost Mediterranean. A. Jurassic. Eratosthenes platform isolated within the southerly neotethys ocean. B. Senonian. Eratosthenes is submerged and covered by pelagic carbonate. Upwelling is concentrated along the Levant coastal area, but is also moderately high on Eratosthenes leading to development of replacement chert. Meanwhile ophiolites are generated above a subduction zone to the north, but Eratosthenes remains unaffected. C. Eratosthenes remains within a remnant oceanic basin, south of a subduction zone, where it is influenced by marginal upwelling. 
The Lower Cretaceous shallow-water carbonates of the Eratosthenes Seamount (Site 967) can be compared with Bahama-type carbonates that formed within the southern Neotethys ocean, in the Levant, southern Turkey, and Greece. Major et al. (Chap. 38, this volume) point out that there are also some similarities with Albian-Aptian shallow-water carbonates in Italy (e.g., Sicily), and dredged material from the Malta escarpment. They also note that limestones of similar age and facies were drilled from the inner wall of the Hellenic Trench during DSDP Leg 13 (Site 127).

In contrast to the Levant shallow-water carbonates, terrigenous clastics are absent from the Lower Cretaceous Eratosthenes succession, reflecting an open-ocean setting away from Tethyan continental margins (Fig. 8A). The incoming of pelagic carbonate above the carbonate platform succession in Eratosthenes could correlate with the marine transgression observed in the southern Levant (Mart et al., 1997). However, some ambiguity still exists concerning the exact timing of the switch to pelagic deposition on the Eratosthenes Seamount. Shallow-water deposition may have ended in the late Aptian, followed by initial pelagic deposition in the early Cenomanian. Alternatively, pelagic deposition may not have begun until the late Cenomanian-Turonian. In either case, pelagic deposition appears to have begun earlier than in the Levant where it became widespread only in the Coniacian (Fig. 8B). In Bey Dağları, in southern Turkey, a comparable switch to pelagic-carbonate accumulation took place in the Cenomanian, earlier than in the Levant, but coeval with, or slightly earlier than on Eratosthenes Seamount. Both the Eratosthenes Seamount and the Bey Dağları are interpreted as carbonate platforms associated with continental fragments within the Neotethys, whereas the Levant is part of the main North African passive margin. The inferred cause of the regional transgression was regional extension that relates to subduction within Neotethys in the Late Cretaceous. Already thinned continental crust readily subsided leading to deep-marine transgression (such as in the Eratosthenes and Bey Dağları units), whereas the thicker continental crust of the Levant margin remained emergent for several million years longer.

Extensive chert and phosphorite, as developed in the Levant margin, are absent from Eratosthenes in the Late Cretaceous, suggesting that the seamount was located beyond the marginal zone of upwelling and high biological productivity. The rare occurrence of laminated, organic-rich sediment (in Hole 967E) might, however, reflect a shortlived drop in the oxygen-minimum zone to intersect the seafloor of Eratosthenes Seamount during certain periods in the Late Cretaceous. Occurrences of replacement chert within pelagic carbonates presumably reflect an original abundance of siliceous micro-organisms (radiolarian) related to, at least, moderate biogenic productivity within this southerly strand of the Upper Cretaceous Neotethyan ocean (Fig. $8 \mathrm{C})$.

During the Tertiary, the early Eocene interval is marked by abundant replacement chert in southern Cyprus, implying high biogenic productivity. This time interval is represented on Eratosthenes only as reworked Eocene planktonic foraminifers in Hole 966F, without preserved siliceous microfossils. The occasional organic-rich layering in the middle Eocene pelagic carbonates could indicate renewed periodic expansion of the oxygen-minimum zone, possibly associated with elevated plankton productivity. One possibility is that siliceous micro-organisms such as radiolarians were originally deposited, but then dissolved during reworking. Alternatively, they never accumulated in great abundance in contrast to southern Cyprus. Southern Cyprus then formed a southward-sloping, submerged ridge in a relatively marginal setting (Robertson, 1976), thus favoring localized upwelling, whereas the Eratosthenes Seamount still lay further south in a more open-ocean setting.

Paleocene and early Eocene planktonic foraminifers are reworked in the middle Eocene pelagic carbonates of Site 966F (Premoli-Silva et al., Chap. 30, this volume). Two alternative explanations are as follows: (1) Pelagic carbonates were initially deposited, but were then reworked as a result of erosion by deep-sea currents; (2) The sediments were deposited, but then removed en masse by slumping. Circumstantial evidence favors the first possibility. Although the cores do not show signs of strong current activity (well-developed scouring, cross lamination, winnowing), the evidence of reworking is most easily explained by the activity of bottom currents. There is evidence of extensional faulting, neptunian fissuring, and sub-horizontal shearing. However, these features, other than the neptunian dikes, are of unknown age (see Flecker et al., Chap. 40, this volume). Reworking could have been activated by subtle tectonic movements, but there is no sign of major tectonic disturbance during the Paleogene, as in the deformation of the Syrian arc of the Levant.

Calciturbidites are absent from the Upper Cretaceous and Eocene pelagic carbonates recovered from Eratosthenes Seamount. This is significant in terms of alternative tectonic models for the origin of the Eratosthenes Seamount. These include the genesis of a rift block related to the North African passive continental margin, as a continental promontory, or as a fragment of thinned continental crust surrounded by oceanic crust within the Neotethys ocean adjacent to the North African continental margin. Onshore in southern Turkey, marginal pelagic successions associated with Upper Cretaceous passive margin sequences typically contain intercalations of calciturbidites reflecting deposition in a slope setting (in the Antalya Complex; Robertson and Woodcock, 1981a, 1981b). In addition, calciturbidites are abundant in the Eocene pelagic carbonate successions of the Lefkara Formation in southern Cyprus. By contrast, Cretaceous successions overlying such drowned carbonate platforms as the Bey Dağları and Barla Dağ carbonate platforms in southern Turkey are mainly represented by pelagic carbonates without such redeposition features. Comparisons favor an origin of the Eratosthenes Seamount as an isolated continental fragment that experienced a continuous rain of pelagic sediment, rather than as part of a rifted continental margin that would be expected to include gravity-deposited sediment. As summarized in Fig. 9, this isolated fragment was initially near sea level, giving rise to carbonate platforms in late Aptian and earlier time, but it then subsided and was overlain by pelagic carbonate in Late Cretaceous-Paleogene time.

\section{CONCLUSIONS}

1. The discovery of Lower Cretaceous shallow-water carbonates and Upper Cretaceous and Paleogene bathyal carbonates on Eratosthenes Seamount (Emeis, Robertson, Richter, et al., 1996; Premoli-Silva et al., Chap. 30, this volume) provides important insights into the paleo-tectonic and paleo-oceanographic setting of Neotethys in the easternmost Mediterranean region.

2. Lower Cretaceous shallow-water facies, including coral and calcareous algae, are similar to the extensive carbonate platforms of the Levant and Southern Turkey, except that terrigenous sediments are absent on Eratosthenes, reflecting a more open-ocean setting.

3. The advent of planktonic foraminifers above Lower Cretaceous neritic carbonates indicates that submergence of the carbonate platform may have occurred in the late Aptian, with fully pelagic conditions being established either by Cenomanian or Turonian time (Premoli-Silva et al., Chap. 30, this volume).

4. The Lower Cretaceous (Cenomanian? to Maastrichtian) and lower Oligocene pelagic carbonates recovered in Hole 967E, and the middle Eocene pelagic carbonates in Hole 966F (Premoli-Silva et al., Chap. 30, this volume) accumulated on a relatively level surface (i.e., a drowned platform), isolated from terrigenous input and the effects of gravitational reworking.

5. The absence of bedded chert and phosphorite suggests that the submerged Eratosthenes Seamount was located seawards of a highproductivity zone affecting the Levant continental margin in the 
Late Cretaceous. Productivity may occasionally have been sufficiently elevated to allow the oxygen-minimum zone to reach the seafloor on the drowned Eratosthenes Seamount, causing the formation of localized intervals of well-laminated, organic-rich carbonates. The absence of burrowing is suggestive of anoxia within these sediments. Sufficient biogenic silica also accumulated to promote formation of replacement chert during diagenesis.

6. The presence of reworked Paleocene and lower Eocene planktonic foraminifers in Hole 966F, and of early to mid-Paleocene and early to middle Eocene forms in Hole 967E (Premoli-Silva et al., Chap. 30, this volume) is indicative of reworking by bottom currents, in a setting that shows some evidence of minor tectonic instability (i.e., presence of local neptunian fissures).

7. The middle Eocene pelagic carbonates in Hole $966 \mathrm{~F}$ differ from deep-water successions in Southern Cyprus, where common gravity deposition and localized slumping indicate that accumulation took place on a topographically irregular seafloor. The Eratosthenes sediments differ from those in the Levant where collision-related deformation of the Syrian arc took place during this time interval.

8. In terms of its regional tectonic setting, the Upper Cretaceous pelagic carbonate succession on Eratosthenes Seamount escaped major tectonic disturbance associated with genesis and displacement of ophiolites in areas further north (e.g., Cyprus), probably because the seamount was then still located well to the south of the active orogenic zone. The Cretaceous and Paleogene Eratosthenes successions are instead consistent with accumulation on an isolated topographic high located within the southerly Neotethyan ocean, adjacent to the North African and Levant continental margins. Eratosthenes shows similarities with successions in the Levant and may mirror the tectonic history of this area, especially the deformation that gave rise to the Syrian arc.

\section{ACKNOWLEDGMENTS}

Thanks go to Diana Baty for drafting the figures and to Yvonne Cooper for help with photography. The manuscript benefited from comments from William V. Sliter and Alessandro Montanari.

\section{REFERENCES}

Almogi-Labin, A., Bein, A., and Sass, E., 1993. Late Cretaceous upwelling along the southern Tethys margin, Israel: interelationship between productivity, bottom water environments, and organic matter preservation. Paleoceanography, 8:671-690.

Almogi-Labin, A., Eshet, Y., Flexer, A., Honigstein, A., Moshkovitz, S., and Rosenfeld, A., 1991. Detailed biostratigraphy of the Santonian/Campanian boundary interval in northern Israel. J. Micropaleontol., 10:39-50.

Baroz, F., 1979. Étude géologique dans le Pentadaktylos et la Mesaoria (Cypre septentrionale) [Ph.D. thesis]. Univ. of Nancy, France.

Bartov, Y., 1974. A structural and paleogeographic study of the central Sinain faults and domes [Ph.D. thesis]. Hebrew Univ. of Jerusalem. (In Hebrew with English abstract)

Bartov, Y., Eyal, Y., Garfunkel, Z., and Steinitz, G., 1972. Late Cretaceous and Tertiary stratigraphy and palaeogeography of southern Israel. Isr. J. Earth Sci., 21:69-72.

Buchbinder, B., Benjamini, C., Mimran, Y., and Gvirtzman, G., 1988. Mass transport in Eocene pelagic chalk on the northwestern edge of the Arabian platform, Shefela area, Israel. Sedimentology, 35:257-274.

Clube, T.M.M., and Robertson, A.H.F., 1986. The paleoration of the Troodos microplate, Cyprus in the plate tectonic framework of the Eastern Mediterranean. Surv. Geophys., 8:375-437.

Ducloz, C., 1972. The geology of the Bellapais-Kythrea area of the central Kyrenia Range, Cyprus. Geol. Surv. Dept. Bull., 6:75.
Eaton, S., and Robertson, A.H.F., 1993. The Miocene Pakhna Formation, Cyprus, and its relationship to the Neogene tectonic evolution of the Eastern Mediterranean. Sediment. Geol. 86:273-296.

Emeis, K.-C., Robertson, A.H.F., Richter, C., et al., 1996. Proc. ODP, Init. Repts., 160: College Station, TX (Ocean Drilling Program).

Garfunkel, Z., 1988. The pre-Quaternary geology of Israel. In Yom-Tov, Y., and Tchernov, E. (Eds.), The Zoogeography of Israel: Dordrecht (Junk Publ.).

Gvirtzman, G., Almogi-Labin, A., Honigstein, A., and Reiss, Z., 1989. Upper Cretaceous high-resolution multiple stratigraphy, northern margin of the Arabian platform, central Israel. Cretaceous Res., 10:107-135.

Haq, B.U., Hardenbol, J., and Vail, P.R., 1987. Chronology of fluctuating sea levels since the Triassic. Science, 235:1156-1167.

Kempler, D., 1994. Tectonic patterns in the easternmost Mediterranean [Ph.D. thesis]. Hebrew Univ.

Kolodny, Y., 1980. Carbon isotopes and depositional environment of a high productivity sedimentary sequence: the case of the Mishash-Ghareb Formations, Israel. Isr. J. Earth Sci., 29:147-156.

Krasheninnikov, V.A., and Kaleda, K.G., 1994. Stratigraphy and lithology of the Upper Cretaceous and Cenozoic deposits of the key Perapedhi section (neautochthon of Southern Cypress). In Krashenninikov, V.A., and Hall, J.K. (Eds.), Geological Structure of the Northeastern Mediterranean (Cruise 5 of the Research Vessel Akademik Nokolaj Strakhov): Jerusalem (Historial Productions-Hall Ltd.), 195-218.

Mantis, M., 1970. Upper Cretaceous-Tertiary foraminiferal zones in Cyprus. Epethris, 3:227-241.

Mart, Y., Robertson, A.H.F., and Woodside, J., 1997. Cretaceous tectonic setting of Eratosthenes Seamount in the eastern Mediterranean Neotethys: initial results of ODP Leg 160. C.R. Acad. Sci. Ser. 2a, 324:127-134.

Moores, E.M., and Vine, F.J., 1971. The Troodos Massif, Cyprus and other ophiolites as oceanic crust: evaluation and implications. Philos. Trans. $R$. Soc. London A, 268:443-466.

Nathan, Y., Shiloni, Y., Roded, R., and Deutch, Y., 1979. The geochemistry of the northern and central Negev phosphorites (southern Israel). Bull. Isr. Geol. Surv., 73:1-43.

Poisson, A., 1979. Recherches geologiques dans les Taurides occidentalses (Turquie) [Ph.D. thesis]. Univ. Paris-Sud, Orsay.

Poisson, A., Akay, E., Dumont, J.F., and Uysal, S., 1984. The Isparta Angle: a Mesozoic paleorift in the Western Taurides. In Tekeli, O., and Göncuölü, M.C. (Eds.), Geology of the Tauris Belt, Proceedings. MTA Ankara, 1116.

Robertson, A.H.F., 1976. Pelagic chalks and calciturbidites from the lower Tertiary of the Troodos Massif, Cyprus. J. Sediment. Petrol., 46:1000710016.

- 1977. The origin and diagenesis of cherts from Cyprus. Sedimentology, 24:11-30.

, 1993. Mesozoic-Tertiary sedimentary and tectonic evolution of neotethyan carbonate platforms, margins and small ocean basins in the Antalya Complex, southwest Turkey. In Macdonald, D.I.M. (Ed.), Sedimentation, Tectonics and Eustasy, Sea-level Changes at Active Margins. Spec. Publ. Int. Assoc. Sedimentol., 20:415-465.

Robertson, A.H.F., Clift, P.D., Degnan, P., and Jones, G., 1991. Palaeogeographic and palaeotectonic evolution of the Eastern Mediterranean Neotethys. Palaeogeogr., Palaeoclimatol., Palaeoecol., 87:289-344.

Robertson, A.H.F., and Hudson, J.D., 1974. Pelagic sediments in the Cretaceous and Tertiary history of the Troodos Massif, Cyprus. In Hsü, K.J., and Jenkyns, H.C. (Eds.), Pelagic Sediments: On Land and Under the Sea. Spec. Publ. Int. Assoc. Sedimentol., 1:403-436.

Robertson, A.H.F., Kidd, R.B., Ivanov, M.K., Limonov, A.F., Woodside, J.M., Galindo-Zaldivar, J., and Nieto, L., 1995. Eratosthenes Seamount, easternmost Mediterranean: evidence of active collapse and thrusting beneath Cyprus. Terra Nova, 7:254-265.

Robertson, A.H.F., and Woodcock, N.H., 1980. Tectonic setting of the Troodos massif in the East Mediterranean. In Malpas, J., Moores, E.M., Panayiotou, A., and Xenophontos, C. (Eds.), Ophiolites: Oceanic Crustal Analogues. Proc. Symp. "Troodos 1987," Nicosia, Cyprus (Geol. Surv. Dep., Minist. Agric. Nat. Resour.), 36-49.

, 1981a. Alakır Çay Group, Antalya Complex, S W Turkey: deposition on a Mesozoic passive carbonate margin. Sediment. Geol., 30:95131. 
, 1981b. Bilelyeri Group, Antalya Complex, S.W. Turkey: deposition on a Mesozoic passive continental margin. Sedimentology, 28:381399

- 1986. The geological evolution of the Kyrenia Range: a critical lineament in the Eastern Mediterranean. In Reading, H.G., Watterson, J., and White, S.H. (Eds.), Major Crustal Lineaments and their Influence on the Geological History of the Continental Lithosphere. Proc. R. Soc. London discussion meeting, A317:141-178.

Şengör, A.M.C., and Yilmaz, Y., 1981. Tethyan plate tectonic evolution of Turkey: a plate tectonic approach. Tectonophysics, 75:181-241.

Shahar, Y., 1968. Type section of the Campanian-Maastrichtian Ghareb Formation in Oron Syncline (northern Negev), stratigraphic section No. 6. Isr. Geol. Surv., Jerusalem.
Steinitz, G., 1977. Evaporite-chert associations in Senonian bedded cherts of Israel. Isr. J. Earth Sci., 26:55-63.

1981. Enigmatic chert structures in the Senonian cherts of Israel. Bull. Isr. Geol. Surv., 75:55-63.

Date of initial receipt: 24 january 1997

Date of acceptance: 24 June 19997

Ms 160SR-035 